\title{
Liberalization in the Process of Economic Development
}





\section{Liberalization in the Process of Economic Development}

EDITED BY

Lawrence B. Krause and Kim Kihwan

UNIVERSITY OF CALIFORNIA PRESS

Berkeley Los Angeles Oxford 
University of California Press

Berkeley and Los Angeles, California

University of California Press, Ltd.

Oxford, England

(c) 1991 by

The Regents of the University of California

\section{Library of Congress Cataloging-in-Publication Data}

Liberalization in the process of economic development / edited by Lawrence B. Krause and Kim Kihwan.

p. $\mathbf{c m}$.

Includes bibliographical references and index.

ISBN 0-520-06357-0 (cloth)

1. Economic policy. 2. Economic development. I. Krause,

Lawrence B. II. Kim, Kihwan.

HD87.L53 1991

$338.9-\mathrm{dc} 20$

90-41127

CIP

Printed in the United States of America

$$
\begin{array}{lllllllll}
1 & 2 & 3 & 4 & 5 & 6 & 7 & 8 & 9
\end{array}
$$

The paper used in this publication meets the minimum requirements of American National Standard for Information Sciences-Permanence of Paper for Printed Library Materials, ANSI Z39.48-1984. 
In Memory of Kim Jae-Ik 
